ElżBIeta Muskat-Tabakowska

Uniwersytet Jagielloński

\title{
Pies na krótkiej smyczy na chwiejnym mostku
}

\section{Preliminaria}

Dwie metafory składające się na tytuł niniejszego eseju należą do Douglasa Hofstadtera, którego rozważania o tłumaczach i tłumaczeniu są od wielu lat inspiracją moich przekładów i prac o przekładzie. Hofstadter - fizyk, specjalista w dziedzinie kognitywistyki i neurobiologii, psycholog, komparatysta i tłumacz poezji - buduje $z$ tych metafor fundament swojego rozumienia roli tłumacza. W obszernej monografii zatytułowanej Le Ton beau de Marot. In Praise of the Music of Language (Hofstadter 1997) pisze:

Tłumacz robi z oryginałem coś podobnego do tego, co impresjonista (powiedzmy van Gogh) robi z krajobrazem: dodaje ów nieuchronny i cenny rys własnej osobowości, który czyni ten proces zasadniczo odmiennym od fotografii. (Hofstadter 1997: 388$)^{1}$

W świecie nauk ścisłych Hofstadter jest znany przede wszystkim jako autor uhonorowanej nagrodą Pulitzera książki Gödel, Escher, Bach: an Eternal Golden Braid („Gödel, Escher, Bach: odwieczny złoty splot”), której podtytuł, dodany

1 Tłumaczenie wszystkich obcojęzycznych cytatów pochodzi od Autorki artykułu E.M.T. 
przez wydawcę jako zwięzły opis tomu, właściwie mówi o Hofstadterze wszystko: „Metaforyczna fuga o umysłach i maszynach, skomponowana w duchu Lewisa Carrolla”. Wbrew pozorom, nie ma w tej książce mowy o relacjach między matematyką (Gödel), malarstwem i grafiką (Escher) oraz muzyką (Bach). Jej niezwykła narracja - głównie dialogi Achillesa z żółwiem - oraz analizy słynnego twierdzenia Gödla, kanonu Bacha i znanej litografii Eschera, na której dwie ludzkie ręce rysują nawzajem same siebie, zmierzają do pokazania czytelnikowi, w jaki sposób ludzki umysł może postrzegać świat, wykraczając poza granice doświadczenia i przemieszczając się między różnymi poziomami rzeczywistości.

$\mathrm{Na}$ ponad 600 stronicach swojej książki Hofstadter analizuje prawie 90 przekładów jednego jedynego wiersza Ma mignonne szesnastowiecznego francuskiego poety, Clémenta Marota. Polemizując z tezą Roberta Frosta, który uważał, że poezją jest to, co ginie w przekładzie, Hofstadter starał się dowieść, że poezja jest przekładalna, szczegółowo analizując w tym celu 88 wersji Ma mignonne (większość stworzył sam, inne są pokłosiem plebiscytu, jaki rozpisał wśród przyjaciół), z których każda stawia sobie za cel oddanie tego, co zostało przez jej autora uznane za translatorską dominantę. I każda zawiera w sobie cenny rys osobowości tłumacza: ów czynnik ludzki, który nieuchronnie naznacza przekład indywidualnym piętnem.

Czynnik ludzki to - w kontekstach teatralnych - po prostu aktorzy, odgrywający na scenie swoje role. Sądzę, że o to właśnie pytali organizatorzy konferencji, której pokłosiem jest niniejszy tom, podkreślając analogię: we współczesnym przekładoznawstwie parający się przekładem człowiek odgrywa rolę (czy też role) tłumacza w teatrum, w którym rozgrywa się sztuka tłumaczenia. Rola obejmuje wszelkie aspekty interakcji między tłumaczącym i tłumaczonym. Co więcej, intertekstualna aluzja do powieści szpiegowskiej Grahama Greene’a The Human Factor („Czynnik ludzki”) także znajduje w tym kontekście szersze uzasadnienie: jak w przypadku dwóch bohaterów Greene’a, osobowość tłumacza przejawia się przecież również w wyznawanych przez niego wartościach - uczciwości, lojalności, poczuciu odpowiedzialności.

Najważniejszym partnerem tłumacza w roli pierwszoplanowego aktora jest język, oglądany nie chłodnym okiem językoznawcy-strukturalisty, lecz w szerszej perspektywie - jako narzędzie i zarazem przedmiot poznania. Tak patrzy na język Hofstadter - badacz ludzkiego umysłu i zachodzących w nim procesów poznawczych. Tak patrzy także - z pozycji językoznawcy - twórca gramatyki kognitywnej języka naturalnego, amerykański uczony Ronald W. Langacker. Obaj - choć nie zawsze mówią to explicite - są zgodni co do kilku podstawowych założeń. Wspólne dla obu jest uznanie roli czynnika ludzkiego przesądzającego o ostatecznym kształcie językowych konwencji i o sposobach ich przełamywa- 
nia, odrzucenie algorytmu jako wzorca działania ustalonych sekwencji reguł gramatycznych, rezygnacja z postulatu przewidywalności, wyłączenie metafory z kategorii językowych dewiacji i wyniesienie jej do roli podstawowego mechanizmu ludzkiego poznania. W takim paradygmacie poezja i gramatyka zbliżają się do siebie: poezja gramatyki pozwala odkrywać i rozumieć tajniki gramatyki poezji.

Relacje między podmiotem i przedmiotem procesu przekładu są nieuchronnie naznaczone subiektywizmem, ponieważ każdy użytkownik języka i każdy tłumacz jako użytkownik języka jest, jak pisze Hofstadter, „istotą ludzką i istotą żywą" (Hofstadter 1997: 387). A zatem nie da się zobaczyć pełni świata oczyma innego, przy czym owym „innym” może się także stać „on sam”, ponieważ „ja tu i teraz” nie jest tożsame z „ja gdzie indziej i kiedy indziej”. Empatia, czyli - mówiąc najogólniej - zdolność widzenia świata z punktu widzenia innego człowieka, pozwala zmniejszyć dystans między „nim samym” i „innym” (dotyczy to oczywiście nie tylko przekładu), ale nigdy nie da się tego dystansu zredukować do zera. Tłumaczowi - jak aktorowi na scenie - empatia jest potrzebna; cytując Hofstadtera, „im bardziej [inny - E.M.T.] jest od nas oddalony - w czasie, przestrzeni, pod względem temperamentu czy ogólnej sytuacji - tym projekcja staje się trudniejsza, a empatia maleje" (Hofstadter 1997: 486). Warto dodać, że we współczesnym językoznawstwie empatia, do niedawna traktowana po macoszemu, powoli zyskuje sobie rację bytu, przyjmując własne, „językoznawcze”, znaczenie: badaczom języka idzie nie tyle o zdolność przyjmowania perspektywy innej osoby, ile o umiejętność językowego wyrażania tej zdolności. Na styku obu znaczeń rysuje się obszar wspólny dla wyznawców teorii Hofstadtera, językoznawców spod znaku Langackera i tłumaczy.

Ze wspólnych założeń wynika szereg ważkich konsekwencji: ostateczny upadek mitu „przezroczystej szyby”, nieuchronność zniekształceń w procesie przekładu (i nie tylko w przekładzie: zniekształca każdy czytelnik każdego tekstu - także oryginalnego), a wreszcie pogodzenie się z tym, że każdy przekład jest, cytując Hofstadtera, „ciągiem twórczych aktów wiernej zdrady” (Hofstadter 1997: 365). W świetle tego paradoksu tłumacz jest jak pies na smyczy: ma pewną swobodę (choć jego twórczość jest zdradą), ale długość smyczy mu ją ogranicza (bo jednak musi pozostać wierny). Jest równocześnie jak budowniczy mostu łączącego dwa brzegi kanionu. Konstruując swój przekład, zaczyna od przerzucenia liny na drugą stronę, potem buduje chwiejną kładkę, którą stopniowo umacnia i ulepsza, a konstrukcja mostu staje się solidniejsza z każdą kolejną „przymiarką” i udoskonaleniem.

Sedno myśli o przekładzie stanowi dla Hofstadtera pojęcie analogii, która jest dla niego „umiejętnością znajdowania relacji i połączeń między różnymi 
elementami rzeczywistości”2. Analogia jest zatem kluczowym składnikiem percepcji i podstawą procesu kategoryzacji. Wszelkiej kategoryzacji - pojęć i elementów języka, struktur semantycznych i konstrukcji składniowych. Jest to umiejętność, dzięki której powstają zarówno kategorie pojęciowe, jak i kategorie gramatyczne. Ale za jej sprawą powstaje także metafora i tworzy się gramatyka. Analogia jest podwaliną języka, kamieniem węgielnym poezji i fundamentem każdego przekładu - zarówno inter-, jak i intralingwalnego. Innymi słowy, teoria analogii Hofstadtera staje się filarem także tego mostu, który łączy „humanistykę” $\mathrm{z}$ „kognitywistyką”. Konsekwencja dla teorii przekładu jest oczywista: celem staje się analogia, a nie tradycyjnie rozumiana ekwiwalencja, której schyłek ogłosił Theo Hermans, pisząc: „Tłumaczenie może dążyć do ekwiwalencji, ale jej osiągniecie sprawia, że jako taki przekład dokonuje aktu samozniszczenia. Ekwiwalencja wyznacza koniec przekładu” (Hermans 36).

Źródłem i zarazem celem analogii jest, jak wiadomo, rozpoznanie relacji podobieństwa, jakie zachodzi między określonymi bytami. Rozpoznania dokonuje heglowski rozum obserwujący - tłumacz w roli czytelnika, czytelnik jako odbiorca przekładu. Rozważając analogię i podobieństwo w kontekście tłumaczenia, francuski semiotyk Philippe Monneret stwierdza po prostu, że dobrym przekładem tekstu jest tekst oparty na dobrej analogii: „A good translation of a text is a good analogy of this text” (Monneret 94). Hofstadter najprawdopodobniej by się zgodził, ale rodzi się oczywiste pytanie o skalę owego dobra. Z pozoru rzecz jest oczywista. Chwiejna kładka sytuuje się u dołu skali, a solidny most - na górze. Tłumacz „zerwany ze smyczy” znajduje się u dołu skali, a karny towarzysz idący równo „przy nodze” - u szczytu. Tłumacz-budowniczy i tłumacz-wierny pies muszą jednak bezustannie rozwiązywać problemy, jakie się rodzą w zderzaniu się przeciwności i stawianych mu sprzecznych wymogów. Ścierają się ze sobą „przeszłe i teraźniejsze «Jaźnie»” (Hofstadter 1997: 485). Dążenie do obiektywizmu spojrzenia (czyli „czystej szyby”), uznawanego za podstawę idealnej analogii, walczy z nieuchronnym subiektywizmem w odbiorze świata (także przedstawionego); trwa nieuchronnie przegrywana walka o obiektywną prawdę, podczas gdy „pomysł, że wszyscy czytelnicy będący rodzimymi użytkownikami danego języka zobaczą «to samo» rozpada się na drobne kawałki” (Hofstadter 1997: 389). Automatyzm w doborze konwencjonalnych elementów języka - dobrze znana badaczom i nauczycielom kompetencja językowa - okazuje się niewystarczający, ponieważ świadomość tłumacza

2 Te zwięzłą definicję znajdujemy w jedynym znanym mi teoretycznym opracowaniu teorii tłumaczenia Hofstadtera: rozprawie doktorskiej Macieja Skrzypeckiego (Skrzypecki, źródło elektroniczne). 
domaga się od niego ponadkonwencjonalnej kreatywności. Elastyczne granice interpretacji przesuwają się po pograniczu oddzielającym kreatywność do bełkotu (por. Brożek). Trwa walka o zachowanie warunków dobrej komunikacji tłumacza z czytelnikiem: o właściwy poziom dokładności przekładanego tekstu, o stopień wyrazistości poszczególnych elementów, o zapewnienie integracji tekstu z universum dyskursu.

Rozszerzając hasło konferencji poprzedzającej powstanie niniejszego tomu, przypomnijmy, że badacze przekładu twierdzą, iż czynnik ludzki w przekładzie literackim nie pojawia się wyłącznie w przekładach tradycyjnie definiowanych jako „artystyczne” czy „literackie”. Zakładając radialność kategorii, każdy tekst da się zdefiniować jako mniej lub bardziej prototypowy „tekst literacki”, a zatem każdy przekład da się określić jako „artystyczny”; intuicyjnie dostrzegane różnice - jeden z filarów genologii - są kwestią stopnia „literackości”. Warto zatem, idąc ścieżką wytyczoną przez Edwarda Balcerzana (por. np. Balcerzan), rozważyć, czym są wyznaczniki literackości. Innymi słowy, poszukać odpowiedzi na pytanie, co jest literaturą, a co literaturą nie jest, skoro literaturę i dyskursy uznawane za nieliterackie łączy wspólne tworzywo języka. Na czym zatem polega owa swoistość tworzywa językowego, o której piszą teoretycy literatury? Teoretycznoliterackie rozważania prowadzą językoznawcę i badacza przekładu na grząski grunt niewiedzy, warto jednak odnotować trzy definicje, które się wydają szczególnie cenne z punktu widzenia tłumacza: ład ponad potrzebę (czyli funkcja poetycka w klasycznym paradygmacie Jakobsona), obecność fikcji literackiej (czyli Ingardenowskie niby-sądy) i obrazowość (czyli Langackerowskie wymiary obrazowania). Każda z nich wymaga jednak wyjaśnienia i doprecyzowania. Bo skoro mamy się wznieść „ponad potrzebę", to jak określić tę "potrzebę"? Jaki jest ontologiczny status faktu, skoro media mówią nam o „faktach prawdziwych” i „faktach fałszywych”, a wśród pisarzy zdarza się postawa, w myśl której „pisząc historię, można zmyślać, ale tworząc literaturę ma się obowiązek pisać prawdę" (Ackroyd 121)? Jakie wreszcie są parametry obrazowania, najwyraźniej rozumianego tu szerzej niż w tradycyjnej poetyce, czyli jako sposoby językowej konstrukcji przekazu (zob. np. Langacker 2009a: 85)?

Wszystkie te pytania domagają się od tłumacza odpowiedzi. Propozycją Hofstadtera jest wieloetapowe budowanie mostu. Na początku jest to „«efekt chwiejnej kładki», pierwsze połączenie brzegów translatorskiego kanionu, skromne, ale ułatwiające budowę kolejnych przęseł, mocniejszych, solidniejszych, subtelniejszych" (Hofstadter 1997: 9). Ten pierwszy etap to projekt (określenie strategii), dobór materiałów - zestawu Langackerowskich wymiarów obrazowania (por. Langacker 2009a: 85-130) - i wreszcie sama konstrukcja (zastosowanie technik). Celem projektu jest według Hofstadtera „przekazanie 
nowej grupie czytelników istoty cudzej wyobraźni i wizji świata” (Hofstadter 1997: 388). Materiał oczywiście stanowi język, jest to jednak surowiec niepewny ze względu na jego wszechobecną metonimiczność. Langacker pisze:

Informacja zakodowana w języku sama w sobie nie precyzuje połączeń i asocjacji przyjmowanych przez uczestników dyskursu na podstawie określonych wyrażeń. Wyrażenia jedynie zapewniają dostęp do elementów, które dają się ze sobą połączyć w określony sposób (Langacker 2009b: 41).

Posługując się metaforą ROZUMIENIE TO DOCHODZENIE DO CELU, Langacker stwierdza, że wobec nieuchronnie metonimicznej natury języka dotarcie pod właściwy adres wymaga - za każdym razem - zastosowania wyobraźni i uruchomienia wiedzy tła - otwartej, uwarunkowanej kontekstem i doświadczeniem encyklopedycznej wiedzy o świecie.

Rozszerzając swoją tezę, Hofstadter twierdzi, że proces przemiany chwiejnej kładki w solidny most stanowi zbiór konstrukcyjnych procedur; wymienia ich listę:

eksploracja, konstrukcja, destrukcja, substytucja, usuwanie, kompresja, ekspansja, przegrupowanie, paralelizacja (przetwarzanie równoległe), interpolacja, porządkowanie... na poziomie słów, interpunkcji, emfazy, fraz, list, zdań, wierszy, akapitów, podrozdziałów, rozdziałów. (Hofstadter 1997: 378)

Warto zauważyć, że jest to niemal dokładny spis technik wskazywanych przez dydaktyków przekładu adeptom sztuki tłumaczenia.

Reasumując, synteza myśli Hofstadtera o przekładzie i myśli Langackera o języku stanowi potencjał, który może tłumaczowi ułatwić przekształcenie kładki w most, a czytelnikom - przejście nad przepaścią; tłumacz kroczy przez swój most odważnie, ale bez pokusy urywania się z krótkiej smyczy. W dalszej części tego eseju postaram się zilustrować powyższe twierdzenie przykładem z własnej translatorskiej praktyki.

\section{Przykład przekładu, czyli studium przypadku}

\subsection{Córka, która sprzedała matkę. Pamiętnik biograficzny}

Książka The Daughter Who Sold Her Mother. A Biographical Memoir Ireny Powell (Powell 2016; 2020) powstała jako „historia życia unoszonego przez 
burzliwe prądy dziejów dwudziestowiecznej Europy - komunizm, syjonizm, faszyzm i antysemityzm odegrały w nim swoje własne role, ale najgłębsze piętno wycisnęła druga wojna światowa” (Powell 2020: 9). Jest „opowieścią o młodej żydowskiej matce żyjącej w Polsce pod niemiecką okupacją” i o dojrzałej kobiecie, której emocjonalne blizny czasu wojny („jak tkwiący w sercu cierń, którego nie da się usunąć”) odbiły się bolesnym piętnem na powojennym życiu jej samej i jej bliskich. Relacja zrodziła się z silnego przeświadczenia córki o tym, że historię matki należy opowiedzieć, ocalić od zapomnienia mimo luk i niedostatków zawodnej pamięci, także - a może przede wszystkim - na użytek anglojęzycznych brytyjskich wnuków „polskiej Babci”. Autorka książki zdaje sobie sprawę, że

w samej naturze narracji tego rodzaju leży pewna fragmentaryczność; niektóre zdarzenia z życia mamy bardzo wyraźnie wryły jej się w pamięć, nad innymi nigdy się nie zastanawiała i nie miała zamiaru się zastanawiać, a jeszcze innych po prostu nie pamiętała (Powell 2020: 11).

Dla tłumacza książka Powell jest szczególnym wyzwaniem. Zapisując po latach opowieść ocalonej z Holokaustu starej kobiety, autorka starała się zachować jej charakterystyczne cechy i oryginalny charakter („tę emfazę, ten ton pogardy, ten gniew i ten humor"), ale bohaterka opowieści mówiła po polsku, natomiast autorka napisała książkę po angielsku. Był to efekt jej świadomego wyboru: nie tylko myśl o anglojęzycznej rodzinie, ale także potrzeba „pewnego oderwania, emocjonalnego dystansu, jaki zapewniało [jej - E.M.T.] pisanie w obcym języku” (Powell 2020: 11). Mój przekład na język polski trzeba więc widzieć jako swoiste ćwiczenie z retranslacji.

Czy jest to jednak przekład artystyczny, to znaczy czy „biograficzny pamiętnik” Powell można zaklasyfikować jako literaturę? Z pewnością tak. Za klucz do jego literackości można zapewne uznać wspomniane „emocjonalne blizny”, które kształtują narrację, nasycając ją „ponad potrzebę” empatią córki i „cierpieniem niezagojonych ran”, „wściekłością, bólem i poczuciem straty” matki, naznaczając opowieść - też „ponad potrzebę” - szczególnym pomnożeniem tożsamości, wielu Jaźni; tej z „tu-i-teraz” i tamtych z „tam-i-wtedy”. Innymi słowy, o literackości tej biografii przesądza językowy kształt tego, co autorka nazywa „emocjonalnym krajobrazem matki”. Ale „ponad miarę” jest też wymóg uważności stawiany czytelnikowi: trud przedzierania się przez gąszcz winietek odmalowanych w drobnych szczegółach, śledzenia konstrukcyjnych meandrów, porządkowania pomieszanych płaszczyzn czasowych. 


\subsection{Dramatis personae}

Zacznijmy zatem od pierwszoplanowych dramatis personae. Jest więc Irena Powell, postać trochę prawdziwa, a trochę literacka, autorka cudzej relacji, którą komentuje z pozycji narratorki. Przedstawicielka „drugiego pokolenia” dziecko rodziców ocalałych z Holokaustu, urodzona w 1941 roku we Lwowie, na dwa tygodnie przed wkroczeniem do miasta Niemców. Córka polskich Żydów, wykształcona w Polsce filolożka, stypendystka Oksfordu, żona brytyjskiego profesora, znawcy teatru japońskiego, matka dwóch brytyjskich synów, japonistka, pracownik naukowy Uniwersytetu Oksfordzkiego. Naznaczona „emocjonalnymi bliznami” rodzinnej przeszłości.

Na widowni teatrum zasiadają projektowani czytelnicy - według najogólniejszego podziału należący do dwóch grup - dzieci Ireny i wszyscy, którzy zechcą przeczytać dzieje życia jej matki w angielskim oryginale, oraz uogólniony wieloosobowy projektowany czytelnik polskiego przekładu. W podwójnej roli widza i aktora występuje tłumaczka - Polka, filolożka (angielska), wychowana i wykształcona w Polsce sprzed transformacji 1989 roku i w Wielkiej Brytanii sprzed brexitu, tłumacz i wykładowca uniwersytecki.

I wreszcie postać najważniejsza: tytułowa matka, osoba o wielu tożsamościach: Sara (Sarna) Rubinstein vel Sarna Malter vel Julia Odarka Wons vel Julia Rubinstein vel Julia Janicka vel „the Polish Babcia” vel Sarna Julia Janicki. Oś czasowa jej życia, timeline, ukazuje zmienne losy jednostki na tle zmiennych kolei państw i narodów. Sara Rubinstein urodziła się w 1911 roku w galicyjskim miasteczku Tartaków w granicach Austro-Węgier. Chodziła do polskiej szkoły, w której uczono także języków ukraińskiego i niemieckiego; Tartaków był odległą prowincją, ale dzieci otrzymywały tam edukację nie tylko wielojęzyczną, ale także wielokulturową. W domu mówiło się w jidysz. Wielojęzyczność i wielokulturowość towarzyszyły zatem Sarze od dzieciństwa. W latach 1918-1920 miasteczko było pod okupacją ukraińską, a po wojnie, na mocy Traktatu ryskiego, znalazło się w granicach Polski. W roku 1925 lub może 1926 Sara postanowiła opuścić ortodoksyjny dom w sztetlu - zdobyć świecką wiedzę i społeczną emancypację. Przykład dawało liczne starsze rodzeństwo, które „zbuntowało się” wcześniej i, zaraziwszy Sarę syjonistycznymi ideałami, obiecywało pomoc i wsparcie. Nie dbając o ojcowskie przyzwolenie, czternastoletnia Sara wyjechała do Krakowa i podjęła naukę w słynnym Gimnazjum Hebrajskim. Nauczyła się hebrajskiego (pierwsze lekcje wymogła na ojcu jeszcze w Tartakowie). Zdała maturę, łącząc naukę z „kondycjami” - korepetycjami dla dzieci zamożnych żydowskich rodzin - co pozwalało jej się utrzymać w Krakowie. W 1934 roku została przyjęta na Wydział Prawa Uniwersytetu Jagiel- 
lońskiego - w czasie, gdy na uczelniach coraz szerzej zaczynano wprowadzać zasady numerus clausus i numerus nullus. Po dwóch latach rzuciła studia. W 1938 roku rozpoczęła naukę w Żydowskiej Szkole Pielęgniarstwa w Warszawie w nadziei, że zawód pielęgniarki zwiększy jej szanse na wyjazd do Hiszpanii, dokąd Mietek B., jej pierwsza miłość, właśnie wyjechał z zamiarem uczestniczenia po stronie republikańskiej w hiszpańskiej wojnie domowej. Wybuch wojny zastał Sarę w Tartakowie, gdzie przyjechała na wakacje. Poznała Romka Maltera, w styczniu 1940 roku została Sarą Malter i w marcu razem z mężem wyjechała do Taganrogu w ramach sowieckiej akcji rekrutacji siły roboczej - podjęła pracę w laboratorium chemicznym, ucząc się od koleżanek języka rosyjskiego. Ale jesienią tego samego roku wróciła do Polski, do Tartakowa, gdzie pracowała w miejscowym nadleśnictwie aż do chwili, gdy widoczna zaawansowana ciąża zmusiła ją do odejścia z pracy. Wyjechała do Lwowa, dokąd wcześniej dotarł jej mąż i gdzie 6 czerwca 1941 roku - na dwa tygodnie przed wkroczeniem do miasta Niemców - urodziła córkę Irenę. Ze Lwowa wjechała w 1942 roku; jej wojenna odyseja trwała do wyzwolenia; walczyła o życie własne i dziecka jako Julia Odarka Wons (na ukraińskich papierach, które jej oddała znajoma Ukrainka), mówiąc po ukraińsku i udając katoliczkę na podkrakowskich wsiach, odwiedzając rodzinę w rzeszowskim getcie, ukrywając męża i kuzynkę pod podłogą izby wynajmowanej od polskich gospodarzy, wreszcie przedostając się do Krakowa, gdzie zastał ją koniec wojny.

Po wojnie Sara-Julia zamieszkała z córką i mężem w Jeleniej Górze. Mówiła po polsku i czuła się Polką. Przyjęła nazwisko męża, który teraz nazywał się Janicki. W roku 1957 w ramach „gomułkowskiej aliji” wyjechała do Izraela do braci i sióstr, którzy w latach trzydziestych wyemigrowali do Palestyny na fali ruchu syjonistycznego. W Izraelu mieszkała do roku 1963, ucząc się hebrajskiego, pracując w opiece społecznej w Tel Awiwie i starając się przystosować do polityki Ben Guriona one country, one language. Z rodzeństwem rozmawiała po polsku i w jidysz, z młodszym pokoleniem - po hebrajsku (który różnił się znacznie od tego, którego przed laty uczyła się w Gimnazjum Hebrajskim w Krakowie). W roku 1963 zdecydowała się na powrót do Polski, mimo że reemigracja nie była łatwa do przeprowadzenia. Zamieszkała z córką; Irena studiowała japonistykę i w 1967 roku dostała stypendium na wyjazd do Oksfordu; Sara (czyli Julia Janicka) została w Warszawie. Wobec „wydarzeń marcowych” rodzina zaczęła namawiać Irenę, żeby nie wracała do kraju, natomiast w Warszawie matce coraz trudniej było znosić rosnące naciski i represje. W 1969 roku zdecydowała się na ponowny wyjazd z kraju - tym razem wiedziała już, że nie może to być Izrael. Zamieszkała we Frankfurcie, dokąd wcześniej dotarł jej mąż. Po jego śmierci, w 1997 roku, Sarę-Julię zabrała do siebie córka, od lat mieszkająca z rodziną 
w Oksfordzie. Sara nigdy nie opanowała angielskiego, a z córką do końca życia rozmawiała po polsku. I po polsku opowiadała jej o swoim życiu.

Córka, która sprzedała matkę wpisuje się w nurt „literatury Holokaustu”, relacji zapisywanych po latach „z perspektywy ocalonego, który wciąż nie jest bezpieczny, nosi bowiem w sobie niedające się uleczyć rany pamięci” (Literatura Holokaustu, źródło elektroniczne). Badania nad tą literaturą mają ogromną bibliografię; badacze podkreślają, że „krajobraz po Holokauście” ukazuje nie tylko traumę ocalonych, ale także „straszliwe dziedzictwo, jakie przejmują [ich] dzieci” (Literatura Holokaustu, źródło elektroniczne). W książce Powell „psychiczne blizny” matki i „straszliwe dziedzictwo” córki wysuwają się na pierwszy plan, a niezwykle istotnym wątkiem jest kwestia tożsamości obu bohaterek. I w moim odczuciu właśnie ten wątek stanowi translatorską dominantę.

\subsection{Tożsamości}

W socjologii tożsamość definiuje się jako zestaw społecznych utożsamień, identyfikacji jednostki, wykorzystywanych przez nią do opisu siebie samej; wyróżnia się dwa rodzaje tożsamości - osobistą (indywidualną) i społeczną (zbiorową). Tożsamość osobista jest konstruktem, na który składają się cechy osobowości; jest to świadomość „bycia sobą”, poczucie własnej odrębności i niepowtarzalności. Determinuje relacje z innymi osobami, określa system wartości jako element danej kultury, odwołuje się do tradycji. Świadomość społeczna natomiast tworzy poczucie przynależności do wspólnoty lub grupy społecznej - także z punktu widzenia zewnętrznego obserwatora. Oba rodzaje budują się w oparciu o szereg wymiarów - etniczny, narodowy, kulturowy, polityczny, religijny, pokoleniowy. Tożsamość jest konstruktem trwałym, ale może ulec modyfikacji pod wpływem zmian, przybierając różne formy. Największe poczucie bezpieczeństwa i przynależności zapewnia jednostce tożsamość nazwana legitymizująca, która wiąże jednostkę z „miejscem urodzenia, rodziną, macierzystym środowiskiem kulturowym” i „zakorzenia” jednostkę w rodzimej kulturze, nadając jej poczucie podmiotowości i zapewniając orientację w świecie (Paleczny 2008: 41-2). Jest osadzona w tradycji i buduje się wokół stałego systemu wartości. Wobec istotnych zmian w życiu jednostki oraz w obliczu zagrożenia następuje (re)konstrukcja tożsamości; buduje się tożsamość oporu reakcja na wyzwania, która stanowi niezbędny element relacji opierających się na „asymetrii położenia” (Paleczny 42-43).

Szczególnym rodzajem tożsamości jest tożsamość patchworkowa (patchwork identity), 
złożona z wielu zmiennych orientacji i postaw, które aktualizowane są w zależności od sytuacji zewnętrznej i indywidualnych potrzeb. W efekcie powstaje tożsamość niejednorodna i eklektyczna, złożona ze sprzecznych aksjologicznie i poznawczo elementów (Kociuba 26).

O tym rodzaju tożsamości mówi się najczęściej w kontekście diaspory; jest to zbiorowa tożsamość uchodźców i imigrantów.

Wszystkie typy tożsamości kształtują się pod wpływem trzech czynników: zwyczajów, religii i języka. Dostrzeganie funkcji języka jako nośnika tożsamości jest oczywiście szczególnie istotne w kontekście omawianego w tym eseju przekładu. Przyjrzyjmy się zatem tożsamościom bohaterek pamiętnika Powell.

\subsection{Sara-Julia}

W narracji Ireny wyraźnie rysuje się dominanta osobistej tożsamości Sary-Julii, powstała z połączenia cech osobowości (wysokie poczucie własnej wartości i siły) z ekstremalnymi okolicznościami. Sara-Julia identyfikuje się jako osoba o dużych możliwościach intelektualnych, dumna z umiejętności przeżycia w straszliwych warunkach czasu Holokaustu. Uważa się za osobę wyjątkową: jest pewna, że żadna inna młoda matka nie zdołałaby uchronić siebie i dziecka przed zagładą, gdyby musiała stawić czoło przeciwnościom, jakie stały się jej udziałem. To przekonanie określa też stosunek Sary do męża (którego wini o brak wsparcia i zdradę) i córki (która powinna być jej wyłączną i dozgonnie wdzięczną dłużniczką). Przekonanie o własnej wyjątkowości rodzi poczucie wyższości w relacjach ze wszystkimi osobami, które nie są „Sarą”.

Tożsamość społeczną Sary buduje jej żydowskość:

I was always very proud of being Jewish [...]. We, the Jewish children... had a very strong sense of our identity (Powell 2016: 48, podkr. E.M.T.)

Byłam dumna z tego, że jestem Żydówką. [...] My, żydowskie dzieci, mieliśmy mocne poczucie własnej?/naszej?/żydowskiej? tożsamości i nigdy w żaden sposób nie czuliśmy się gorsi dlatego, że byliśmy Żydami (Powell 2020: 86).

Lista możliwych polskich odpowiedników zaimka dzierżawczego our wskazuje na interpretacyjne niuanse: „własnej” odnosi się do zbioru jednostkowych tożsamości dzieci z Tartakowa; „naszej” - łączy ich wspólnotę zaimkiem soli- 
darności (por. tzw. solidarity we); przymiotnik „żydowskiej” jest semantycznie najbardziej transparentny, a jego użycie wskazywałoby na troskę o polskiego czytelnika.

W latach szkolnych Sary jej tartakowska tożsamość była tożsamością legitymizującą. Ale porównując życie w domu rodzinnym z życiem „młodych rebeliantów” - starszych braci Aszera i Abrahama, którzy porzucili studiowanie Tory, przestali chodzić do synagogi, odrzucili tradycyjny ortodoksyjny styl życia i zachłysnęli się ideałami syjonizmu - Sara wkroczyła w fazę młodzieńczego buntu. Organizacja Ha-Szomer, do której należeli młodzi Rubinsteinowie, „uwalniała ich od ograniczeń życia w mówiącej w jidysz żydowskiej wspólnocie” i „dawała [...] poczucie dumy z tego, że jesteśmy Żydami i poczucie własnej tożsamości” (Powell 2020: 115). Pierwsza przemiana w tożsamości Sary oznaczała zatem przejście od legitymizacji do oporu. Przemianę tę dobrze widać w opisie sceny z krakowskiej restauracji, do której „wyzwolona” Sara zaprosiła rodziców; pozornie opis ten nie nastręcza tłumaczowi żadnych kłopotów. Ale oto ojciec Sary, postępując zgodnie z nakazem swojej religii, ukradkiem polewa pod stołem ręce wodą ze swojej szklanki.

I almost died of embarrassment! (Powell 2016: 29, podkr. E.M.T.).

komentuje tę anegdotę Sara. Lista polskich odpowiedników angielskiego embarrassment jest dość długa i obejmuje całą gamę uczuć: „wstyd, żenada, zakłopotanie, zażenowanie, skrępowanie, kłopotliwa sytuacja” (słownik angielsko-polski, źródło elektroniczne) Tłumaczowi potrzeba empatii, która by mu pozwoliła poczuć „siłę” popychającą Sarę ku tożsamości oporu.

Opór stał się skutkiem dokonanego wyboru: przynależność do młodzieżowej organizacji komunistycznej oznaczała, że Sara była

...doubly removed from her Jewish roots - as an assimilated and liberated young woman and as a believer in the socialist revolution... «She used to spit as he passed the synagogue» my cousin told me, a hint of righteousness in her voice (Powell 2016: 371, podkr. E.M.T.).

[Związki mojej matki z nielegalną komunistyczną organizacją młodzieżową] oderwały ją od żydowskich korzeni - zarówno jako wyzwoloną młodą kobietę i jako wyznawczynię idei rewolucji socjalistycznej... «Pluła przechodząc obok synagogi»... powiedziała mi kuzynka tonem ??? (Powell 2020: 20). 
No właśnie, jakim tonem? Angielskie righteousness tłumaczy się jako „prawość, cnota, cnotliwość, sprawiedliwość, słuszność” (por. słownik angielsko-polski, źródło elektroniczne) - „czynienie tego, co słuszne”. Tłumacz musi zdecydować, czy owa kuzynka broniąca żydowskiej tożsamości przemawia z pozycji uznania słuszności własnej postawy, czy też może Irena odczytuje w jej tonie solidarność z żydowską tożsamością społeczną? Przyjmując punkt widzenia Ireny, ominęłam tę rafę, wybierając zwrot „ton nie dopuszczający dyskusji”.

Odrzucenie tożsamości Sary bywało mistyfikacją Julii. Próbując ratować siebie i dziecko, postawiona przez żołnierzy gestapo w obliczu starego Żyda, który miał potwierdzić jej żydowską tożsamość, Sara oświadcza z pogardą: „Ja nie rozmawiam z żydowskim parchem” (Powell 2020: 329). Przecież zmieniła (ołówkiem!) kształt nosa na zdjęciu Julii Odarki Wons w kenkarcie i nauczyła się mówić po ukraińsku, więc jest Ukrainką!

Jak zrozumieć i jak oddać całą złożoność emocji? Bo „[j]eśli [Sara] mimo wszystko silnie trzymała się swojej żydowskiej tożsamości (co robiła przez całe życie)”, pisze Powell, „to bardziej z silnego poczucia niesprawiedliwości i dyskryminacji niż z przywiązania do żydowskich tradycji” (Powell 2020: 481). Równocześnie jednak zachowała społeczną świadomość Polki. Nie mogąc się odnaleźć w sowieckim Taganrogu,

She was desperate to go back home (Powell 2016: 151).

Rozpaczliwie chciała wrócić, ale dokąd? Do siebie? Do domu rodzinnego w Tartakowie? A więc do żydowskich korzeni i żydowskiej tożsamości? Czy do polskiej ojczyzny? Tej, która później ją wypędziła i skazała na powtórną emigrację? A więc znów legitymizacja i opór.

Po wielu latach, jakie minęły od jej pierwszego związku z Mietkiem B., Sara wspomina (z zazdrością? z nostalgią?):

the easy mix of Jewish and Polish traditions (Powell 2016: 117)

w Mietka „całkowicie zasymilowanej żydowskiej rodzinie z Częstochowy”. Jakie jest w jej ocenie (a może w ocenie Ireny?) to "połączenie tradycji żydowskiej i polskiej"? Słowniki angielsko-polskie podpowiadają: łatwe, proste; niewymuszone, dogodne, nieskomplikowane, przystępne, ustępliwe, spokojne, beztroskie; lekkie, delikatne, łagodne; pobłażliwe, naturalne, swobodne, luźne; łatwo dostępne, nasycone. Każde $\mathrm{z}$ tych określeń implikuje odmienną motywację i inną ocenę żydowsko-polskiej tożsamości państwa B, podejmowaną 
z innego punktu widzenia. Wybrałam przymiotnik „łatwe” (8) - wciąż jednak nie wiem czy słusznie.

Ważnym czynnikiem kształtującym patchworkową tożsamość Sary widzianej przez nią samą, przez otaczających ją ludzi i przez czytelników książki napisanej przez jej córkę - jest mozaika języków, których Sara używa. Zna jidysz, polski, ukraiński, rosyjski, hebrajski, niemiecki i (słabo) angielski. Opowiada swoje losy po polsku, wtrącając do narracji słowa i zwroty z pozostałych języków - drobne wskazówki kierujące do poszczególnych „łatek” patchworkowej tożsamości. Obcojęzyczne wtręty podkreślają rodzimą polskość narracji. Autorka sygnalizuje status polszczyzny, pozostawiając w oryginale te wypowiedzi Sary, które z definicji wymagają języka ojczystego i są szczególnie silnie nacechowane emocjonalnie: „.Bardzo mnie serce bolało, czy ty możesz to sobie w ogóle wyobrazić? A gdzie miałam iść? Absolutnie nie miałam pojęcia”, itp. Powell uważa, że są one nieprzetłumaczalne na język angielski; tłumaczka jej książki z angielskiego też wywiesza białą flagę, choć z nieco innej przyczyny.

\subsection{Irena}

Czynnikiem kształtującym osobistą tożsamość Ireny jest „trauma drugiego pokolenia” - „psychiczna blizna” dzieci ocalonych z Holokaustu. Jest osobą bilingwalną - między językami polskim i angielskim - a jej świadomość językową z pewnością podnosi znajomość egzotycznego dla Polki języka japońskiego. Tożsamość osobista Ireny - podobnie jak tożsamość jej matki - także jest patchworkowa, legitymizująca (polska i brytyjska, być może z elementami japońskimi), w latach młodości niepozbawiona poznawczych dysonansów, rodzących się na tle religijnym i kulturowym. Widać to szczególnie w sytuacjach, w których, czując się ,jedną z nich”, doznaje społecznego wykluczenia ze wspólnoty polskich dzieci. Podczas pobytu w polskim sanatorium odkrywa, że

There are [...] rather disquieting things that I never mention to my parents... my cohorts [...] formed a naturally cohesive group, united by their faith. [...] I was truly the odd one out, and as a Jew, untrustworthy to boot (Powell 2016: 404 -405, podkr. E.M-T.).

Są też jednak inne niepokojące/zatrważające sprawy, o których nigdy nie wspominam rodzicom... moi koledzy i koleżanki, mimo różnic pochodzenia i różnych części kraju, z których przyjechali, tworzyli w sposób naturalny zwartą grupę, którą jednoczyła wspólna religia. 
[...] Naprawdę... nie pasowałam, a w dodatku jako Żydówka nie zasługiwałam na zaufanie.

Jakie są te „inne sprawy”? Tylko niepokojące czy aż zatrważające? Słownik podaje obie możliwości i nie ułatwia tłumaczce decyzji...

Polska tożsamość Ireny zostaje po raz pierwszy zakwestionowana podczas pewnych świąt Bożego Narodzenia, a tożsamość żydowska (zapewne ukrywana przez rodziców żyjących w powojennej Polsce) dopiero się kształtuje:

For my parents Christmas was a purely secular event. Having abandoned in their youth their Jewish faith and traditions, in post-war Poland they replaced them with the festivities of Christmas. [...] Was it done for the sake of their child, so that she would feel no different from other children? If so, they succeeded, albeit only in part; that Christmas, I had my first inkling of being Jewish (Powell 2016: 335, podkr. E.M.T.).

Dla moich rodziców Boże Narodzenie było czysto świeckim wydarzeniem. Porzuciwszy w młodości żydowską religię i tradycje, w powojennej Polsce zastąpili je obchodami świąt Bożego Narodzenia. [...] Może robili to dla dziecka, po to, żeby córka nie czuła, że jest inna niż inne dzieci? Jeśli tak, to im się udało, choć tylko częściowo: w tamto Boże Narodzenie pierwszy raz zaczęlam podejrzewać, że jestem Żydówką (Powell 2020: 437).

Czy to inkling to było „przeczucie”? „Blade pojęcie”? A może „podejrzenie”? Każdy ze słownikowych odpowiedników wyraża przecież inny stosunek Ireny (wtedy? a może w czasie, gdy powstawała książka?) do rodzącej się żydowskiej tożsamości.

Zgodnie ze swoim zamysłem, Irena stara się zachować postawę „obserwującej obecności” tłumaczki polskojęzycznej narracji matki na język angielski, który - jako neutralny - pozwala jej zachować „dystans i bezstronność” (distance and detachment). Ale emocjonalna więź z matką i dysonans poznawczy - cecha charakterystyczna patchworkowej tożsamości - nie zawsze na to pozwalają.

\subsection{Tłumaczka}

Zmagania tłumaczki z tym tekstem dotyczą zarówno jej własnej tożsamości, jak i wpływających na nią stereotypów. Niemcy to okrutni okupanci i zbrodniarze, Polacy - bohaterowie zasługujący na las drzewek w Yad Vashem, Ukraińcy - za- 
jadli nacjonaliści, Rosjanie - prymitywni grabieżcy, a Żydzi - syjoniści (w kontekście wydarzeń marcowych 1968 roku). Na ten ostatni stereotyp nakłada się równie stereotypowy obraz matki-Żydówki: Jewish mother. Tymczasem żaden z tych stereotypów etnicznych (a wiążą się z nimi językowe nawyki!) nie znajduje odbicia w narracji o Sarze Rubinstein/Julii Odarce Wons/Julii Janickiej, a jej opowieści o dobrych Niemcach i złych Polakach nie tylko nie przystają do polityki historycznej ostatnich lat, ale owym stereotypom wręcz rzucają wyzwanie. A jest to niewątpliwie także wyzwanie dla tłumacza - poza czysto językowym „problemem trzeciego języka” w przekładzie, który najczęściej okazuje się językiem drugim: po-yewreiski dom zachowuje w polskim kontekście swój ukraiński koloryt, Aktion, Aussiedlung, Arbeitslager, Einsatzgruppen budzą dreszcz grozy, propusk, o który Sara zabiega w Taganrogu, pokazuje jej brak znajomości sowieckich procedur, okrzyk Za batiuszku! Na Berlin przywołuje kontekst pochodu Armii Czerwonej z 1945 roku, ale woziwoda, planty, kondycja i pierożki nikną, wpisane w polski tekst...

\subsection{Budowanie mostu}

\subsubsection{Projekt: konstruowanie tożsamości budowniczego}

Projektując swój most, tłumacz musi się zmierzyć z własną tożsamością. Ideałem byłyby zapewne Piagetowskie procesy asymilacji (oznaczającej „rezygnację z siebie”, co pozostawałoby w zgodzie z upadłym mitem „przezroczystej szyby”) lub akomodacji (czyli przyjęcia w pełni nowych struktur poznawczych, co wymaga maksymalnej empatii). W praktyce będzie to pewnie raczej postawa nazywana strategią unikania sprzeczności (godzenia), a więc wykorzystywania tego, co wspólne w obu kulturach i językach (czyli analogia Hofstadtera), uzupełniona strategią poszerzania kodu (czyli nabywania „docelowej” wiedzy tła). Wszystkie te strategie są omawiane w kontekście zjawiska nazywanego „stresem emigracyjnym” (por. np. Wysocka), ale metaforę TŁUMACZ TO EMIGRANT można by chyba z powodzeniem włączyć do listy metafor ilustrujących istotę przekładu. Tożsamość tłumacza byłaby zatem tożsamością współodczuwającego emigranta, przerzucającego pierwszą chwiejną kładkę na drugi brzeg kanionu.

\subsubsection{Konstrukcja: filary i przęsła}

Budowniczy przedstawiony w tym eseju opiera swój (konkretny) most na kilku (konkretnych) filarach podtrzymujących (konkretne) przęsła. Filar pierwszy stanowią fakty - oczywisty fundament każdego procesu przekładu; właśnie ze względu na tę oczywistość nie poświęciliśmy mu w niniejszym eseju zbyt wiele 
miejsca. Filarem drugim - bez którego most się chwieje - jest obrazowanie, także uważane za oczywistość przez wszystkie teorie przekładu. W omawianym wyżej przykładzie szczególnie istotny jest jednak aspekt obrazowania nazywany przez Langackera obiektyfikacja (por. np. Langacker 2009), czyli rozważenie roli narratora jako podmiotu i jednocześnie przedmiotu obserwacji. Obecność narratorki „pierwotnej” (Sara-Julia) i „wtórnej” (Irena) wyraźnie przejawia się w książce Powell na płaszczyźnie językowej: polskie cytaty w tłumaczonych na angielski wypowiedziach Sary, obcojęzyczne wtręty; nacechowane emocjonalnie wypowiedzi obu bohaterek jako dramat wielu tożsamości, to jest kolejny filar mostu.

Filar trzeci, być może najważniejszy, jest zbudowany ze splotu wielu tożsamości. Niełatwo dostrzec, że trzeba go zbudować, bo składa się z pozornie niewiele znaczących językowych niuansów, ale bez niego most się chwieje i brak mu solidnej nawierzchni.

\subsubsection{Dziury w moście}

Mimo starań o najsolidniejszą nawet konstrukcję, w nawierzchni mostu zdarzają się dziury. Można ich nie zauważyć, ale budowniczy mostów wie, że one tam są, kiedy sam się potyka, na przykład, o „trzeci język”... Kiedy indziej mimo największych starań któreś przęsło się chwieje. Na przykład, oburzona marcowymi wydarzeniami w Polsce Sara woła (a Irena nie tłumaczy):

Przeze mnie Polski może nie być!

Sens wynika z kontekstu, ale ta przedziwna forma! Zdanie pozostaje enigmatyczne aż do chwili, gdy z radia usłyszę stary przebój Bai mir bist du szein. Eureka! Zza językowej kalki wychyla się żydowska tożsamość Sary, której językiem ojczystym mimo wszystko pozostał jidysz z galicyjskiego sztetla. Czym i jak można tę dziurę załatać?

\subsubsection{Smycz}

I ostatnie pytanie: kto trzyma krótką smycz? W szerszym wymiarze dzierżą ją w dłoniach autorzy polityki historycznej i specjaliści od poprawności politycznej. Z tej smyczy świadomy zawodowej etyki tłumacz ma pełne prawo się zerwać, rezygnując $z$ autocenzury. Ale drugą smycz trzyma autorka książki - autoryzując przekład, nie raz z oburzeniem pisała mi na marginesie: „Mama by tak nigdy nie powiedziała!”. 


\subsection{Coda}

Odwołując się do znanego przysłowia, banalnej mądrości narodu, powyższe rozważania mogą sprawiać wrażenie dzielenia włosa na czworo. Na swoje usprawiedliwienie mam jednak mocne przeświadczenie, że prawdziwym problemem tłumacza bywa brak uważności: nie dostrzega drobniutkich szczegółów, w których tkwi translatorski diabeł. Most jest z pozoru solidny, ale dzięki diabelskim sztuczkom albo ma dziury w nawierzchni, albo się chwieje, mimo że tłumaczowi udało się jakoś przedostać na drugą stronę.

\section{| Bibliografia}

Ackroyd, Peter. Three brothers. Londyn: Chatto \& Windus, 2003.

Balcerzan, Edward. Literackość. Modele, gradacje, eksperymenty. Toruń: Wydawnictwo Naukowe Uniwersytetu Mikołaja Kopernika, 2013.

Brożek, Bartosz. Granice interpretacji. Kraków: Copernicus Center Press, 2014.

Cieślikowska, Dominika. „Tożsamość społeczna”. Edukacja antydyskryminacyjna. Podręcznik trenerski. Red. M. Branka, D. Cieślikowska. Kraków: Stowarzyszenie Willa Decjusza, 2010. S. 66-74.

Gentner Deidre, Holyoak Keith J., Kokinov Boris, red. The Analogical Mind. Perspectives from Cognitive Science. Cambridge, Mass.: the MIT Press, 2001.

Hermans, Theo. Narada języków. Przeł. zespół. Kraków: Wydawnictwo Uj, 2005. Hofstadter, Douglas R. Le Ton beau de Marot. In Praise of the Music of Language. Nowy Jork: Basic Books, 1997.

Hofstadter, Douglas R. "Analogy as the core of cognition". The Analogical Mind. Perspectives from Cognitive Science. red. D. Gentner, K.J. Holyoak, B. Kokinov. Cambridge, Mass.: the MIT Press, 2001. S. 116-144.

Hofstadter Douglas R. Sander Emmanuel. Surfaces and Essences: Analogy as the Fuel and Fire of Thinking, New-York: Basic Books, 2013.

Itkonen, Esa. "Iconicity, analogy, and universal grammar". Journal of Pragmatics 22 (1994). S. 37-53.

Kociuba, Jolanta. „Kulturowe tło dysfunkcji tożsamości jednostki”. Kultura $i$ Wartości 18 (2016). S. 15-35.

Langacker, Ronald W. Gramatyka kognitywna. Wprowadzenie. Przeł. zespół. Kraków: Universitas, 2009a.

Langacker, Ronald W. Investigations in Cognitive Grammar. Berlin: Mouton de Gryuter, 2009b.

„Literatura Holokaustu”. Web. 01.11.2019. <https://tinyurl.com/yceommx2> 
Monneret, Philippe. "Iconicity as a Function of Analogy". Book of abstracts. The $12^{\text {th }}$ International Symposium on Iconicity in Language and Literature | 3-5 May 2019. S. 94-95.

Paleczny, Tadeusz. Socjologia tożsamości. Kraków: Oficyna Wydawnicza AFM, 2008.

Powell, Irena. The Daughter Who Sold Her Mother. A Biographical Memoir Bloomington: authorHouse, 2016.

Powell, Irena. Córka, która sprzedała matkę. Wspomnienia rodzinne. Przeł. Elżbieta Tabakowska. Kraków: Austeria, 2020.

Skrzypecki, Maciej. Praktyka translatorska Stanisława Barańczaka w świetle teorii analogii Douglasa R. Hofstadtera. Niepublikowana rozprawa doktorska. 2018. Web. 19.05.2020. <https://tinyurl.com/yc739jom>

Słownik angielsko-polski. Web. 01.05.2020. <https://tinyurl.com/y9ma4v6e>

Tabakowska, Elżbieta. „Empatia - w języku, w tekście, w przekładzie”. Kognitywistyka 3. Empatia, obrazowanie i kontekst jako kategorie kognitywistyczne. Red. H. Kardela, Z. Muszyński, M. Rajewski. Lublin: Wydawnictwo umcs, 2012. S. 153-166.

Tabakowska, Elżbieta. Językoznawstwo zastosowane. Kraków: Austeria, 2019. Wysocka, Ewa. „ «My» i «oni» - dlaczego tak trudno być razem? Odpowiedź pedagoga, psychologa i socjologa”. Migracja, uchodźstwo, wielokulturowość. Zderzenie kultur we wpółczesnym świecie. Red. D. Lalak. Warszawa: Wyd. Akademickie żAK, 2007. S. 13-63.

\section{| Abstrakt}

\section{ElżBieta Muskat Tabakowska}

Pies na krótkiej smyczy na chwiejnym mostku

Punktem wyjścia artykułu jest tytułowa metafora, której Douglas Hofstadter używa, mówiąc o przekładzie. Hofstadter opisuje zadanie stojące przed tłumaczem, zwłaszcza w przypadku tekstu literackiego, jako dzieło budowniczego mostu, spinającego dwa brzegi kanionu oddzielającego oryginał od przekładu. Konstrukcja, która jest z początku jedynie chwiejną kładką, stopniowo zmienia się w solidny most, w miarę jak tłumacz odkrywa coraz głębsze warstwy znaczeń. Ten proces, nieuchronnie subiektywny, wymaga skupienia uwagi na rozmaitych aspektach przekładanego tekstu. Są one uderzająco podobne do wymiarów obrazowania w modelu gramatyki i języka naturalnego stworzonym przez Ronalda Langackera. W szerszej perspektywie ta zbieżność stanowi argument przemawiający za transdyscyplinarnym podejściem do problematyki przekładu. 
Pracą tłumacza kierują jego kompetencja, wyobraźnia i empatia, ale jednocześnie podlegają one restrykcjom tytułowej „krótkiej smyczy”: ograniczeniom stwarzanym przez język, ale także przez wymogi określonego kontekstu. Jako ilustrację, autorka przytacza przykłady zaczerpnięte $z$ własnego warsztatu tłumacza. Jest to tekst, w którym różne, a czasem wzajemnie sprzeczne, tożsamości bohaterki wymagają od tłumacza szczególnej uważności wobec leksykalnych i stylistycznych detali. To one tworzą smycz, jednocześnie umożliwiając tłumaczowi budowanie mostu.

Słowa kluczowe: analogia, czynnik ludzki, empatia, literackość, obiektyfikacja, obrazowanie, poznanie, subiektywizm, tożsamość, uważność

\section{| Abstract}

\section{ElżBieta Muskat-Tabakowska}

\section{A Dog on a Short Leash on a Rickety Foot-bridge}

The inspiration for the paper was the metaphor that Dougles Hofstadter applies to translation. He defines the task of the translator - with particular reference to translation of literary texts - as that of the builder of a bridge that spans the canyon, joining its two sides: the original and the translation. An initial rickety foot-bridge, it gradually turns into a sturdy construction with the translator's repeated attempts at discovering ever-deepening layers of meaning. Inevitably subjective, the building process requires the translator's concentration upon individual dimensions of the translated text. These dimensions, or aspects, come strikingly close to what is defined as dimensions of imagery in Ronald Langacker's model of grammar and natural language. In a wider perspective, the convergence is an argument for transdisciplinarity as a valid approach to translation studies.

The translator is led by his own competence, imagination and the feeling of empathy, but at the same time they are constrained by "a short leash": restrictions imposed by languages, cultures and the peculiarities of individual context. To illustrate the point, the author discusses a text (taken from her own translator's dossier) in which multiple, and sometimes conflicting, identities of the protagonist require particular attention to lexical and stylistic minutiae. It is such details that constitute the leash, at the same time enabling the translator to construct the bridge.

Keywords: analogy, human factor, empathy, literariness, objectification, imagery, cognition, subjectivism, identity, mindfulness 


\section{| Nota o autorze}

Elżbieta Muskat-Tabakowska - emerytowany profesor Uniwersytetu Jagiellońskiego. W latach 2002-2012 Kierownik Katedry unesco do Badań nad Przekładem i Komunikacją Międzykulturową. Anglistka, specjalista w dziedzinie językoznawstwa kognitywnego i teorii przekładu. Tłumacz konferencyjny. Autorka tłumaczeń licznych tekstów literackich i historiograficznych. Jej dorobek obejmuje siedem książek z zakresu językoznawstwa i teorii przekładu oraz ponad 200 oryginalnych artykułów naukowych, publikowanych w Polsce i zagranicą. Visiting Professor na kilku europejskich uniwersytetach. Autorka programu studiów drugiego stopnia w zakresie przekładu, zakwalifikowanego do sieci European Master's in Translation. E-mail: elżbieta.tabakowska@gmail.com 
